\title{
Assessment of physicochemical and bacteriological parameters in surface water of Padma River, Bangladesh
}

\author{
Md. Ayenuddin Haque ${ }^{1} \cdot$ Md. Abu Sayed Jewel ${ }^{1} \cdot$ Mst. Papia Sultana $^{2}$
}

Received: 5 October 2017 / Accepted: 13 December 2018 / Published online: 27 December 2018

(c) The Author(s) 2018

\begin{abstract}
In the present study, surface water samples were collected during three seasons (summer, monsoon and winter) from four different study sites (T-dam, Padma Garden, I-dam and Talaimari point) of Padma River at Rajshahi, Bangladesh, and various physicochemical and bacterial parameters were analyzed based on standard methods. Significant differences $(p<0.05)$ in physicochemical parameters were observed among the seasons and sites except for water temperature. However, except for fecal coliform, other bacterial parameters such as total heterotrophic bacteria, total coliform and Vibrio cholerae counts showed significant differences $(p<0.05)$ among the seasons, while difference among the sites was insignificant $(p<0.05)$. The result also showed that all the bacterial parameters were maximum during summer and minimum during monsoon season. Untreated sewage and industrial effluents together with reduced water flow and water level were found to increase bacterial counts during summer at Site 2 (Padma Garden). Although the present situation is not serious and alarming enough, the river water requires intensive monitoring to improve its quality for better and sustainable management.
\end{abstract}

Keywords Physicochemical parameters $\cdot$ Coliform bacteria $\cdot$ Vibrio cholerae $\cdot$ Padma River

\section{Introduction}

Global freshwater scarcity due to the pollution of water demands for integrating water management and monitoring all over the world (Dahunsi et al. 2014). Physicochemical and microbial quality of river water is now in great stress by gulping a huge amount of industrial and household disposal (Koshy and Nayar 1999). Therefore, assessment of water quality in terms of physicochemical and microbial aspects can help to take effective management decision to prevent those (Behbahaninia et al. 2009).

Rajshahi City, located in the northwest part of Bangladesh on the bank of the River Padma, has experienced considerable growth over the past few decades. These residential and commercial establishments along the River Padma cause discharge of wastewater either directly into the river or into the drains which subsequently find their way into the river.

Md. Abu Sayed Jewel

jewelru75@yahoo.com

1 Department of Fisheries, University of Rajshahi, Rajshahi, Bangladesh

2 Department of Statistics, University of Rajshahi, Rajshahi, Bangladesh
Hence, there is a possibility that the aquatic environment of the river may be affected somehow by these pollutants. High temperature makes the environment hotter, drier and ultimately results in frequent droughts that deplete necessary river flows to dilute pollutants entering into the river (Banglapedia 2004). Therefore, seasonal variations in both of the anthropogenic and natural processes such as temperature and precipitations affect the quality of river water and lead to different attributes between seasons. Thus, it is important to perform river quality assessment to detect the alterations of the water quality and evaluate pollution sources.

Effective monitoring of physicochemical and microbiological parameters can prevent river water pollution (Chandra et al. 2006), and this type of initiative has a special significance to protect human health from water pollution (APHA 1981). Indicator bacteria, such as total coliform (TC) and fecal coliforms (FC), are useful for the assessment of fecal pollution (APHA 1995). Detailed knowledge of fecal pollution in aquatic environments is crucial for maintaining healthy water body for recreational and economic purposes (Farnleitner et al. 2001). Concentrations of heterotrophic bacteria and Vibrio cholera can be a threat together with increasing water temperatures and decomposition of organic 
matter in Padma River. That can cause cholera disease through the faster growth rate of this pathogen in aquatic environments (Koelle et al. 2005). However, bacterial study in Padma River is very limited and thus a detailed empirical study is needed to assess the present water quality and bacterial parameters of this river. For this purpose, this study was aimed at analyzing some selected physicochemical and bacteriological parameters of surface water of Padma River.

\section{Materials and methods}

\section{Selection of study area and sample collection}

The present study was conducted at four sites (T-dam, Padma Garden, I-dam and Talaimari point) along the Padma River covering most parts of Rajshahi City Corporation. Location and description of sampling sites are shown in Fig. 1 and Table 1. Sampling was done on three respective seasons, namely summer, monsoon and winter, in the year 2016. For the physicochemical analysis, $500 \mathrm{ml}$ of water sample has been collected from the selected sites. On-site measurement of some physicochemical parameters was performed, while others were transported to the laboratory in dark polyethylene plastic bottle and ice box. For the bacteriological analysis, another $500 \mathrm{ml}$ of water samples has also been collected from the selected sampling points and the samples were delivered to the laboratory as quickly as possible; i.e., the time gap between sampling and analyses was below $3 \mathrm{~h}$.

\section{Analysis of physicochemical parameters}

Surface water temperature was measured using a thermometer. Water $\mathrm{pH}$ was measured using an electronic pH meter (Jenway 3020). The biological oxygen demand $\left(\mathrm{BOD}_{5}\right)$ of each water sample was measured using the OxiDirect BOD system (HACH) over 5 days of incubation

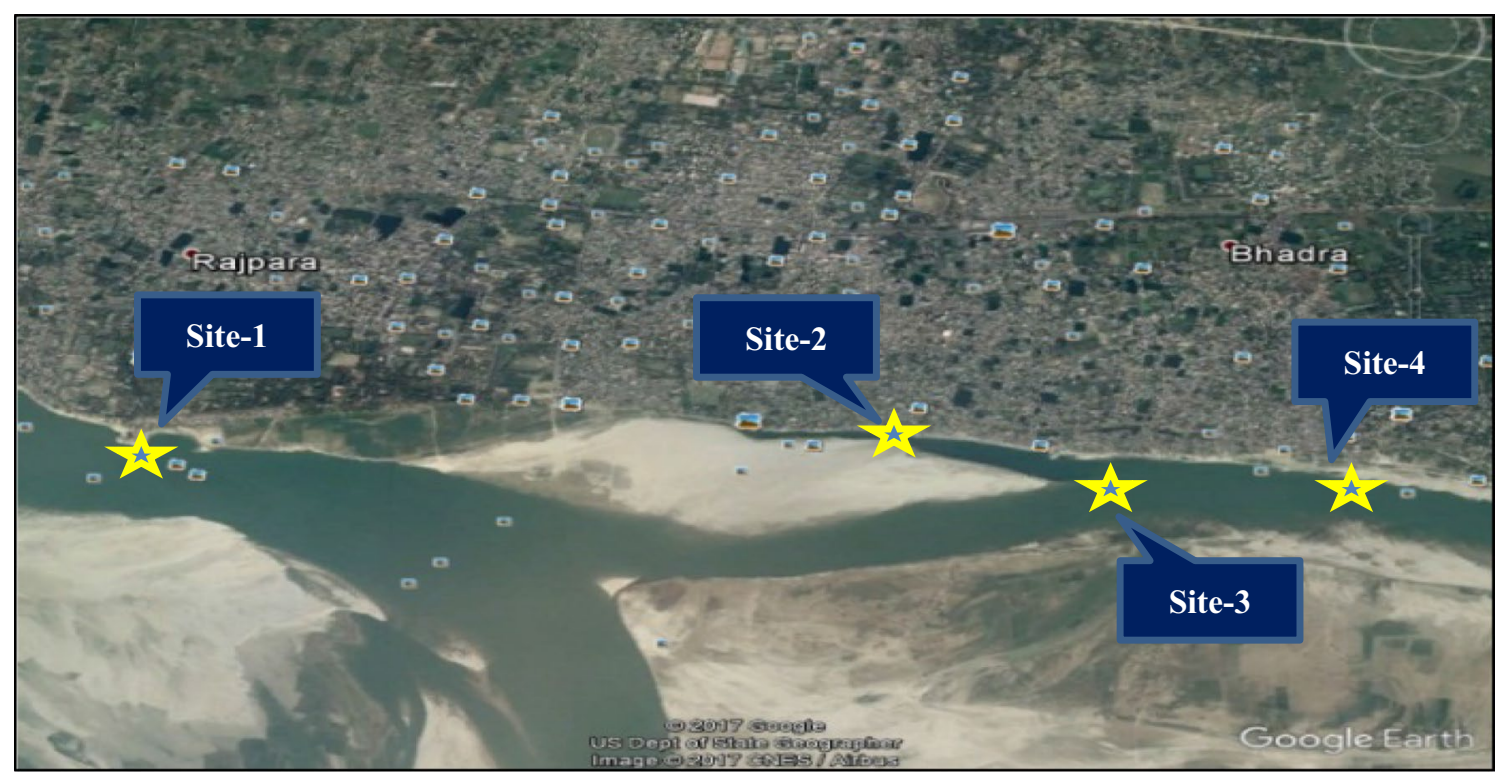

Fig. 1 Location of the study sites (yellow stars). Modified from Google Earth 2017

Table 1 Sampling sites, sampling code and observation

\begin{tabular}{|c|c|c|c|}
\hline Sampling station & Sampling code & Coordinates & Observations \\
\hline T-dam & Site 1 & $\begin{array}{l}\text { Latitude: } \mathrm{N}-24^{\circ} 21^{\prime} 42.41^{\prime \prime} \\
\text { Longitude: } \mathrm{E}-88^{\circ} 34^{\prime} 31.18^{\prime \prime}\end{array}$ & $\begin{array}{l}\text { Discharge of effluent from some household garbage, no human activities except } \\
\text { recreational activities }\end{array}$ \\
\hline Padma Garden & Site 2 & $\begin{array}{l}\text { Latitude: } \mathrm{N}-24^{\circ} 21^{\prime} 42.30^{\prime \prime} \\
\text { Longitude: E- } 88^{\circ} 35^{\prime} 52.44^{\prime \prime}\end{array}$ & $\begin{array}{l}\text { Direct discharges of effluent from vegetable markets and slaughter discharges; } \\
\text { discharge from household septic tanks, more human activities as recreational } \\
\text { site }\end{array}$ \\
\hline I-dam & Site 3 & $\begin{array}{l}\text { Latitude: N-24²1'34.95" } \\
\text { Longitude: E- } 88^{\circ} 36^{\prime} 39.92^{\prime \prime}\end{array}$ & $\begin{array}{l}\text { Direct discharges of effluent from household septic tanks, more human activities } \\
\text { as recreational site }\end{array}$ \\
\hline Talaimari point & Site 4 & $\begin{array}{l}\text { Latitude: N-2421'29.30" } \\
\text { Longitude: E- } 88^{\circ} 37^{\prime} 30.55^{\prime \prime}\end{array}$ & No human activities and no source of discharge into the river \\
\hline
\end{tabular}


period. Dissolved oxygen (DO), total hardness and total alkalinity were measured by using a portable aquaculture kit (Model FF2, HACH, USA). Electrical conductivity (EC) and total dissolved solids (TDS) were measured with an EC, TDS tester (Adwa AD31 waterproof EC/TDS Testers). Nitrate-nitrogen $\left(\mathrm{NO}_{3}-\mathrm{N}\right)$, phosphate-phosphorus $\left(\mathrm{PO}_{4}-\mathrm{P}\right)$ concentrations were measured using the Hach Kit (DR/2020, a direct-reading spectrophotometer) with high-range chemicals (Nitra Ver. 5 Nitrate Reagent Powder Pillows for $\mathrm{NO}_{3}-\mathrm{N}$ and Phos. Ver. 3 Phosphate Reagent Powder Pillows for $\mathrm{PO}_{4}-\mathrm{P}$ analysis).

\section{Bacteriological analysis}

Spread plate method was used to count total heterotrophic bacteria (THB) on nutrient agar media (HiMedia) using $0.1 \mathrm{ml}$ of suitable aliquots. Incubation was done at $37{ }^{\circ} \mathrm{C}$ for $24-48 \mathrm{~h}$, and colonies were counted on a digital colony counter. Indicator bacteria (TC and FC) were evaluated by the most probable number (MPN) method where 10,1 and $0.1 \mathrm{ml}$ aliquots of water samples were inoculated in fermentation tubes containing MacConkey broth (HiMedia) (APHA 1998). The incubation period was $37^{\circ} \mathrm{C}$ for $24 \mathrm{~h}$. Positive tubes were indicated by the production of acid and gas in inverted Durham tube. A loopful of broth from each positive tube was inoculated into the brilliant green lactose bile (BGLB) broth, and incubation was done at $37{ }^{\circ} \mathrm{C}$ for $24-48 \mathrm{~h}$. Durham tubes with gas formation were considered as positive, and final count of total coliform was done as MPN/100 ml. Completed test of total coliform was performed by plating a loopful of broth from each positive BGLB tube onto an eosin methylene blue (EMB) agar plate (HiMedia) and incubating it at $37^{\circ} \mathrm{C}$ for 24-48 h. Positive complete test was confirmed by the appearance of colonies with green metallic sheen. Final fecal coliform count as MPN/100 ml was calculated based on the completed test. Enumeration of $V$. cholerae was also done by spread plating on Thiosulphate Citrate Bile Salts (TCBS) agar plates (HiMedia). Yellow colonies are primarily selected as $\mathrm{VC}$ and finally confirmed by biochemical test (oxidase test).

\section{Statistical analysis}

The data were analyzed by the use of Statistical Package for Social Science (SPSS software Version 20.0). Two-way ANOVA was used to show the interactions between the sites and the seasons at significance level of $p<0.05$. Correlation coefficient test was used to determine whether there was a relationship between water quality parameters and bacterial parameters seasonally.

\section{Results and discussion}

\section{Physicochemical parameters}

The physicochemical parameters of different seasons and sites of water measured during the study period with their interactions are shown in Table 2. Except temperature, all the physicochemical parameters have significant differences $(p<0.01)$ among the seasons and sites. It is common phenomenon that during summer month, air temperature becomes increased and subsequently does the water temperature. Recorded water temperature showed significant $(p<0.05)$ seasonal variation which is lower in winter and higher in summer season. Decreasing water level and increasing amount of insoluble pollutants during summer make the water hotter, which is in agreement with the findings of Boyle and Fraleigh (2003) and Ezzat et al. (2012) where they also reported that discharge of pollutants can increase the temperature of water. During the study period, it was found that Site 2 was mostly polluted by dumping of household and municipal waste. That makes the $\mathrm{pH}$ acidic at Site 2 by decomposition of organic matter. Bhouyan (1979) and Mahmood et al. (1992) reported that industrial and municipal waste can significantly influence the $\mathrm{pH}$ of the water at the dumped site. Increased microbial decomposition of large amount of organic matter at Site 2 also caused a significant depletion of DO. Significant seasonal and spatial changes in DO content were also observed during the study period. The highest concentration of DO at Site $4(8.70 \pm 0.13 \mathrm{mg} / \mathrm{l})$ during winter season indicates recovery of river water from organic pollution. TDS concentrations of the study areas were below the maximum allowable limit $(500 \mathrm{mg} / \mathrm{l})$ of World Health Organization (WHO 2008) as well as the standard of Department of Environment (DoE 1997), Bangladesh (1000 mg/l). Low water level, reduced water flow, discharge of domestic sewage, industrial wastewater and agricultural activities increase the TDS of river water at Site 2 during summer season. The water of Padma River is not saline but interestingly it got higher conductivity values during summer at Site 2 and Site 3. We can assume that it may happen due to the presence of a large amount of total dissolved solids as a result of the dumping of domestic and municipal sewage. It was also observed that total hardness was highest at Site 2, which was recognized as more polluted site as it receives huge amount of city garbage and municipal waste through large drains. Similar result was also reported by Roy and Kumar (2002), where they confirmed that the sewage effluents are responsible for high level of total hardness in river water. Lower value of total alkalinity during monsoon might be due to the dilution effect of water that reduces the concentration of ions in water 


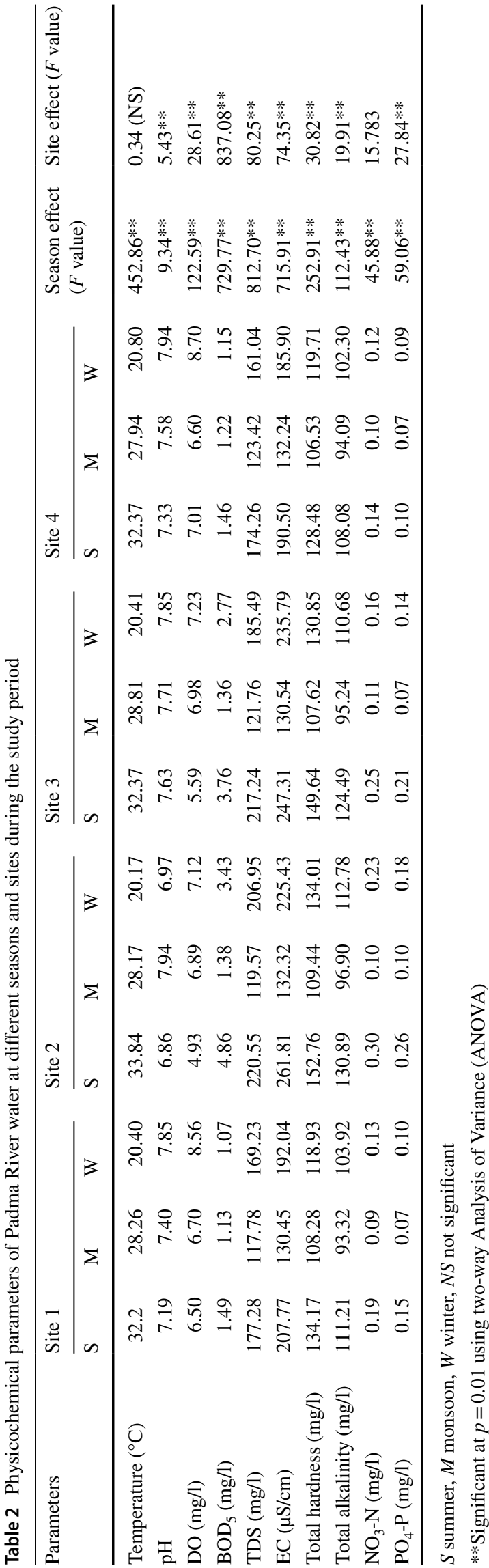

(APHA 1998). The highest total alkalinity observed during summer at Site 2 might be due to disposal of domestic and municipal waste into the river. Higher value of total alkalinity in summer season was also found by Rai et al. (2012) at Harmu River in Ranchi city, Jharkhand, India. The high level of $\mathrm{BOD}_{5}$ (particularly during the dry season) during the study period also indicates the presence of excessive amount of bacteria in the water, which consume the oxygen from the water column. Higher $\mathrm{BOD}_{5}$ values at Site 2 suggest that this site was rich in organic matter content which is being introduced in the rivers by anthropogenic activities. Prasanna and Ranjan (2010) and Mishra et al (2014) also reported that $\mathrm{BOD}_{5}$ of water can be affected by organic content of the water body. The higher value of $\mathrm{NO}_{3}-\mathrm{N}$ and $\mathrm{PO}_{4}-\mathrm{P}$ at Site 2 might also be due to the disposal of higher amount of fertilizers, municipal wastewaters and effluents of septic tank. However, the observed values for $\mathrm{PO}_{4}-\mathrm{P}$ were found well below the $\mathrm{DoE}$ (1997) standard $(6 \mathrm{mg} / \mathrm{l})$ for aquatic life during both dry and wet seasons.

\section{Enumeration of bacterial microorganisms}

Microbial pollution of surface water can be detected by the changes in abundance of bacterial population (Kavka and Poetsch 2002). The presence of bacteria in surface water not only indicates the fecal contamination of water but also the potential human health risks (Baghel et al. 2005). During the study period, the microbial pollution of surface water of Padma River was assessed by monitoring both indicator and pathogenic bacteria (Table 3).

THB impaired the quality of the river water by depleting oxygen immediately from the water during the decomposition of the incoming effluents (Garnier et al. 1991). Significantly higher cell counts of THB during summer may be due to the higher water temperature that increases the enzymatic activity of microbes to heavily proliferate during this season (El-Fadaly et al. 2001; Sabae et al. 2014). Therefore, temperature as well as seasonal variation can be recognized as an important factor that influences the bacterial growth (WHO 2003; Neumann et al. 1972; Al-Kareem et al. 2015).

Followed by THB, TC count was also significantly higher during summer at Site $2\left(160.00 \times 10^{3} \mathrm{MPN} / 100 \mathrm{ml}\right)$ and lower during monsoon at Site $4\left(0.14 \times 10^{3} \mathrm{MPN} / 100 \mathrm{ml}\right)$. In general, the higher counts of coliform bacteria at Site 2 were attributed to the rapid growth of the population in that area that was encouraged by discharging of domestic wastes containing fecal matters through city drains and open defecation along the banks of the river. On the other hand, cold climatic condition of winter season was not supportive for bacterial duplication and makes the lower count of total coliform during winter (Tiefenthaler et al. 2008). Generally, the number of total TCs 
Table 3 Bacterial parameters of Padma River water at different seasons and sites during the study period

\begin{tabular}{|c|c|c|c|c|c|c|c|c|c|c|c|c|c|c|}
\hline \multirow[t]{2}{*}{ Parameters } & \multicolumn{3}{|l|}{ Site 1} & \multicolumn{3}{|l|}{ Site 2} & \multicolumn{3}{|c|}{ Site 3} & \multicolumn{3}{|c|}{ Site 4} & \multirow{2}{*}{$\begin{array}{l}\text { Season } \\
\text { effect ( } F \\
\text { value) }\end{array}$} & \multirow[t]{2}{*}{ Site effect ( $F$ value $)$} \\
\hline & S & M & W & S & M & $\mathrm{W}$ & S & M & W & $\mathrm{S}$ & M & W & & \\
\hline THB $\left(\times 10^{4} \mathrm{cfu} / \mathrm{ml}\right)$ & 6.42 & 0.76 & 3.02 & 8.78 & 0.83 & 4.06 & 7.12 & 0.78 & 3.95 & 4.76 & 0.85 & 2.47 & $48.709 *$ & 2.565 (NS) \\
\hline $\mathrm{TC}\left(\mathrm{MPN} \times 10^{3} / 100 \mathrm{ml}\right)$ & 11.00 & 0.21 & 9.40 & 160.00 & 0.20 & 54.0 & 92.0 & 0.24 & 24.00 & 2.20 & 0.14 & 2.60 & 3.090 & $2.138(\mathrm{NS})$ \\
\hline $\mathrm{FC}\left(\mathrm{MPN} \times 10^{2} / 100 \mathrm{ml}\right)$ & 0.90 & 0.10 & 0.20 & 2.20 & 0.20 & 1.40 & 1.30 & 0.20 & 1.20 & 0.40 & 0.04 & 0.10 & $7.325 * *$ & $4.266(\mathrm{NS})$ \\
\hline $\mathrm{VC}\left(\times 10^{3} \mathrm{cfu} / \mathrm{ml}\right)$ & 2.75 & 0.29 & 1.79 & 5.21 & 0.35 & 2.51 & 4.70 & 0.30 & 2.67 & 1.48 & 0.36 & 1.12 & $13.271^{*}$ & $2.515(\mathrm{NS})$ \\
\hline
\end{tabular}

$T H B$ total heterotrophic bacteria, $T C$ total coliform, $F C$ fecal coliform, $V C V$. cholerae, $c f u$ colony forming unit, $M P N$ most probable number, $S$ summer, $M$ monsoon, $W$ winter, $N S$ not significant

*Significant at $p<0.01$ and **significant at $p<0.05$ using two-way Analysis of Variance (ANOVA)

during the study period was higher than FC, which might be due to the fact that FC is a subset of TC (Prescott et al. 1996).

FC count was highest during summer at Site $2\left(2.20 \times 10^{2}\right.$ MPN/100 ml) and lowest at Site $4\left(0.04 \times 10^{2} \mathrm{MPN} / 100 \mathrm{ml}\right)$ during monsoon season. Most of the septic tanks of Rajshahi City are connected with municipal drains, which are one of the major sources of fecal coliform bacteria in Padma River. Most of the household garbage and industrial garbage flow into the Padma River through the drains located at Site 2, which contributed to the higher fecal coliform level at this location. It is a common practice for people living along the river to discharge their domestic and agricultural wastes as well as human excreta into river directly which are also responsible for bringing about higher FC counts at Site 2 .

Another study revealed that higher TC and FC were strongly associated with rainfall and sewage sources (Crowther et al. 2001; Vincent et al. 2006). However, the higher concentration of fecal coliform during summer season might be the reason for low water level, high organic matter, low bacterivores and optimum growth-supporting nutrient that favor bacterial growth. Similar result was also reported by Jithesh and Radhakrishnan (2015) in water of Chaliyar River, Kerala, India. They also reported higher cell count of fecal coliform during summer season. Higher temperature is also attributed to high load of indicator bacteria which was early reported by Isobe et al. (2004). There was also a significant difference $(p<0.05)$ of FC counts among seasons while differences among sites were insignificant (Table 3).

In the present study, significantly higher VC count was also recorded during summer at Site $2\left(5.21 \times 10^{3} \mathrm{cfu} / \mathrm{ml}\right)$ and the lowest at Site $1\left(0.29 \times 10^{3} \mathrm{cfu} / \mathrm{ml}\right)$ during monsoon season. The possible reason for higher VC during summer might also be due to low water level and sewage contamination which is in agreement with Kenyon et al. (1984).

\section{Relationship between physicochemical and bacteriological parameters}

The relationships between physicochemical and bacterial parameters of Padma River water during the three studied seasons are shown in Tables 4, 5 and 6, respectively. During summer season, THB has significant positive correlation with $\mathrm{NO}_{3}-\mathrm{N}, \mathrm{PO}_{4}-\mathrm{P}$ and $\mathrm{FC}$, while it has significant negative correlation with DO. TC has significant positive correlation with $\mathrm{BOD}_{5}, \mathrm{EC}, \mathrm{TH}, \mathrm{TA}, \mathrm{NO}_{3}-\mathrm{N}, \mathrm{PO}_{4}-\mathrm{P}$ and $\mathrm{FC}$ and significant negative correlation with DO. FC has significant positive correlation with $\mathrm{TA}, \mathrm{NO}_{3}-\mathrm{N}$ and $\mathrm{PO}_{4}-\mathrm{P}$ and significant negative correlation with DO. VC has significant positive correlation with TDS, EC, TH, $\mathrm{TA}, \mathrm{NO}_{3}-\mathrm{N}$ and $\mathrm{PO}_{4}-\mathrm{P}$ (Table 4). During monsoon season, THB has significant positive correlation with EC and VC, while TC did not show significant relation with any of the physicochemical and bacterial parameters. FC showed significant positive correlation with $\mathrm{DO}$ and $\mathrm{BOD}_{5}$, and $\mathrm{VC}$ was strongly influenced by EC and THB (Table 5). During winter season, THB showed significant positive correlation with $\mathrm{EC}, \mathrm{TH}, \mathrm{FC}$ and $\mathrm{VC}$ while significant negative correlation with DO. TC has significant positive correlation with TDS, $\mathrm{NO}_{3}-\mathrm{N}$ and $\mathrm{PO}_{4}-\mathrm{P}$. FC was significantly and positively correlated with $\mathrm{BOD}_{5}, \mathrm{EC}, \mathrm{TH}, \mathrm{TA}, \mathrm{PO}_{4}-\mathrm{P}$ and THB, while it has significant negative correlation with DO. However, VC only has significant positive correlation with EC and THB (Table 6). The negative influence of DO on bacterial parameters during summer and winter seasons agrees with the higher bacterial density which causes the depletion of DO that could be anticipated to the higher rate of microbial decomposition of the excessive organic matter discharged directly into water body (Singh et al. 2002). High $\mathrm{BOD}_{5}$ values and temperature also support the much proliferation of bacteria during this season since $\mathrm{BOD}_{5}$ provides a direct measurement of state of pollution. Relationship between $\mathrm{BOD}_{5}$ and microbial count implies that at high organic loading rates, the ecosystem favors the growth of anaerobes (Mtui and Nakamurs 2006). Although during monsoon season water level of river was high, significant positive relation of $\mathrm{FC}$ with $\mathrm{DO}$ and $\mathrm{BOD}_{5}$ indicates the mixing of domestic wastes along with flood water. 
Table 4 Correlation matrix of physicochemical and bacterial parameters of Padma River during summer season

\begin{tabular}{|c|c|c|c|c|c|c|c|c|c|c|c|c|c|c|}
\hline & Temp. & $\mathrm{pH}$ & DO & $\mathrm{BOD}_{5}$ & TDS & EC & TH & TA & $\mathrm{NO}_{3}-\mathrm{N}$ & $\mathrm{PO}_{4}-\mathrm{P}$ & THB & $\mathrm{TC}$ & $\mathrm{FC}$ & VC \\
\hline Temp. & 1 & & & & & & & & & & & & & \\
\hline $\mathrm{pH}$ & -0.773 & 1 & & & & & & & & & & & & \\
\hline DO & -0.810 & 0.351 & 1 & & & & & & & & & & & \\
\hline $\mathrm{BOD}_{5}$ & 0.817 & -0.288 & $-0.976^{*}$ & 1 & & & & & & & & & & \\
\hline TDS & 0.674 & -0.089 & $-0.955^{*}$ & $0.976^{*}$ & 1 & & & & & & & & & \\
\hline $\mathrm{EC}$ & 0.743 & -0.239 & $-0.993 * *$ & $0.975^{*}$ & $0.979 *$ & 1 & & & & & & & & \\
\hline $\mathrm{TH}$ & 0.698 & -0.168 & $-0.982 *$ & $0.970^{*}$ & $0.987 *$ & $0.997 * *$ & 1 & & & & & & & \\
\hline TA & 0.796 & -0.285 & $-0.993 * *$ & $0.994 * *$ & $0.979 *$ & $0.994 * *$ & $0.988^{*}$ & 1 & & & & & & \\
\hline $\mathrm{NO}^{3}-\mathrm{N}$ & 0.798 & -0.365 & $-0.997 * *$ & $0.957^{*}$ & 0.938 & $0.989^{*}$ & $0.976^{*}$ & $0.982 *$ & 1 & & & & & \\
\hline $\mathrm{PO}^{4}-\mathrm{P}$ & 0.798 & -0.365 & $-0.997 * *$ & $0.957^{*}$ & 0.938 & $0.989 *$ & $0.976^{*}$ & $0.982 *$ & $1.000 * *$ & 1 & & & & \\
\hline THB & 0.825 & -0.495 & $-0.970 *$ & 0.899 & 0.858 & 0.945 & 0.921 & 0.934 & $0.983^{*}$ & $0.983^{*}$ & 1 & & & \\
\hline TC & 0.876 & -0.401 & $-0.981^{*}$ & $0.993 * *$ & 0.947 & $0.967 *$ & $0.953^{*}$ & $0.988^{*}$ & $0.967 *$ & $0.967 *$ & 0.929 & 1 & & \\
\hline FC & 0.897 & -0.545 & $-0.976^{*}$ & 0.934 & 0.871 & 0.944 & 0.918 & $0.951^{*}$ & $0.979^{*}$ & $0.979^{*}$ & $0.987 *$ & $0.966^{*}$ & 1 & \\
\hline VC & 0.688 & -0.197 & $-0.983^{*}$ & 0.947 & $0.965^{*}$ & $0.994 * *$ & $0.994 * *$ & $0.976^{*}$ & $0.984 *$ & $0.984 *$ & 0.945 & 0.936 & 0.928 & 1 \\
\hline
\end{tabular}

Temp. temperature, $D O$ dissolved oxygen, $B O D_{5}$ biological oxygen demand, $T D S$ total dissolved solids, $E C$ electrical conductivity, $T H$ total hardness, TA total alkalinity, THB total heterotrophic bacteria, TC total coliform, $F C$ fecal coliform, VC V. cholerae

*Correlation is significant at the 0.05 level (2-tailed). ${ }^{* *}$ Correlation is significant at the 0.01 level (2-tailed)

Table 5 Correlation matrix of physicochemical and bacterial parameters of Padma River during monsoon season

\begin{tabular}{|c|c|c|c|c|c|c|c|c|c|c|c|c|c|c|}
\hline & Temp. & $\mathrm{pH}$ & DO & $\mathrm{BOD}_{5}$ & TDS & $\mathrm{EC}$ & TH & TA & $\mathrm{NO}_{3}-\mathrm{N}$ & $\mathrm{PO}_{4}-\mathrm{P}$ & THB & $\mathrm{TC}$ & FC & VC \\
\hline Temp. & 1 & & & & & & & & & & & & & \\
\hline $\mathrm{pH}$ & 0.112 & 1 & & & & & & & & & & & & \\
\hline DO & 0.812 & 0.644 & 1 & & & & & & & & & & & \\
\hline $\mathrm{BOD}_{5}$ & 0.555 & 0.871 & 0.934 & 1 & & & & & & & & & & \\
\hline TDS & -0.064 & 0.165 & -0.128 & -0.065 & 1 & & & & & & & & & \\
\hline $\mathrm{EC}$ & -0.721 & 0.561 & -0.271 & 0.081 & 0.406 & 1 & & & & & & & & \\
\hline $\mathrm{TH}$ & 0.101 & 0.516 & 0.515 & 0.618 & -0.759 & 0.040 & 1 & & & & & & & \\
\hline TA & 0.156 & $0.992 * *$ & 0.692 & 0.905 & 0.044 & 0.491 & 0.615 & 1 & & & & & & \\
\hline $\mathrm{NO}_{3}-\mathrm{N}$ & 0.609 & 0.557 & 0.659 & 0.630 & 0.658 & 0.036 & -0.221 & 0.504 & 1 & & & & & \\
\hline $\mathrm{PO}_{4}-\mathrm{P}$ & -0.226 & 0.829 & 0.375 & 0.653 & -0.287 & 0.603 & 0.806 & 0.862 & 0.000 & 1 & & & & \\
\hline ТHB & -0.654 & 0.483 & -0.309 & 0.005 & 0.639 & $0.961^{*}$ & -0.216 & 0.388 & 0.194 & 0.397 & 1 & & & \\
\hline $\mathrm{TC}$ & 0.896 & 0.146 & 0.831 & 0.611 & -0.485 & -0.728 & 0.492 & 0.236 & 0.292 & 0.040 & -0.785 & 1 & & \\
\hline $\mathrm{FC}$ & 0.690 & 0.709 & $0.975^{*}$ & $0.960 *$ & -0.275 & -0.175 & 0.689 & 0.771 & 0.517 & 0.549 & -0.271 & 0.800 & 1 & \\
\hline VC & -0.700 & 0.503 & -0.315 & 0.017 & 0.548 & $0.986^{*}$ & -0.123 & 0.417 & 0.116 & 0.475 & $0.994 * *$ & -0.781 & -0.252 & 1 \\
\hline
\end{tabular}

Temp. temperature, $D O$ dissolved oxygen, $B O D_{5}$ biological oxygen demand, $T D S$ total dissolved solids, $E C$ electrical conductivity, $T H$ total hardness, $T A$ total alkalinity, $T H B$ total heterotrophic bacteria, $T C$ total coliform, $F C$ fecal coliform, VC V. cholerae

*Correlation is significant at the 0.05 level (2-tailed). **Correlation is significant at the 0.01 level (2-tailed)

\section{Conclusions}

It can be concluded that the water of the Padma River is contaminated with domestic waste, fecal materials and industrial wastewater. The counts of THB, TC, FC and VC were highest at Site 2 (Padma Garden) during summer season which indicates household and recreational activities should be in control during this season. The present study suggests a regular monitoring and effective management strategy to be taken to protect this water body from further pollution.

Open Access This article is distributed under the terms of the Creative Commons Attribution 4.0 International License (http://creativeco mmons.org/licenses/by/4.0/), which permits unrestricted use, distribution, and reproduction in any medium, provided you give appropriate credit to the original author(s) and the source, provide a link to the Creative Commons license, and indicate if changes were made. 
Table 6 Correlation matrix of physicochemical and bacterial parameters of Padma River during winter season

\begin{tabular}{|c|c|c|c|c|c|c|c|c|c|c|c|c|c|c|}
\hline & Temp. & $\mathrm{pH}$ & DO & $\mathrm{BOD}_{5}$ & TDS & EC & $\mathrm{TH}$ & TA & $\mathrm{NO}_{3}-\mathrm{N}$ & $\mathrm{PO}_{4}-\mathrm{P}$ & THB & $\mathrm{TC}$ & $\mathrm{FC}$ & $\mathrm{VC}$ \\
\hline Temp. & 1 & & & & & & & & & & & & & \\
\hline $\mathrm{pH}$ & 0.765 & 1 & & & & & & & & & & & & \\
\hline DO & 0.745 & 0.658 & 1 & & & & & & & & & & & \\
\hline $\mathrm{BOD}_{5}$ & -0.735 & -0.774 & $-0.980^{*}$ & 1 & & & & & & & & & & \\
\hline TDS & -0.872 & -0.897 & -0.917 & $0.957^{*}$ & 1 & & & & & & & & & \\
\hline $\mathrm{EC}$ & -0.670 & -0.473 & $-0.974^{*}$ & 0.911 & 0.811 & 1 & & & & & & & & \\
\hline $\mathrm{TH}$ & -0.712 & -0.732 & $-0.987 *$ & $0.998 * *$ & 0.939 & 0.932 & 1 & & & & & & & \\
\hline TA & -0.813 & -0.742 & $-0.991 * *$ & $0.986^{*}$ & $0.960 *$ & 0.942 & $0.985^{*}$ & 1 & & & & & & \\
\hline $\mathrm{NO}_{3}-\mathrm{N}$ & -0.824 & $-0.958^{*}$ & -0.847 & 0.921 & $0.984 *$ & 0.706 & 0.895 & 0.903 & 1 & & & & & \\
\hline $\mathrm{PO}_{4}-\mathrm{P}$ & -0.836 & -0.879 & -0.937 & $0.976^{*}$ & $0.997 * *$ & 0.836 & $0.961 *$ & $0.971^{*}$ & $0.979 *$ & 1 & & & & \\
\hline THB & -0.859 & -0.654 & $-0.973^{*}$ & 0.934 & 0.920 & $0.954^{*}$ & 0.937 & $0.980^{*}$ & 0.834 & 0.923 & 1 & & & \\
\hline $\mathrm{TC}$ & -0.849 & -0.943 & -0.869 & 0.932 & $0.992 * *$ & 0.738 & 0.907 & 0.922 & $0.998 * *$ & $0.987 *$ & 0.864 & 1 & & \\
\hline $\mathrm{FC}$ & -0.762 & -0.708 & $-0.998 * *$ & $0.990 * *$ & 0.941 & $0.956^{*}$ & $0.994 * *$ & $0.996 * *$ & 0.881 & $0.958^{*}$ & $0.970^{*}$ & 0.900 & 1 & \\
\hline VC & -0.835 & -0.522 & -0.937 & 0.863 & 0.838 & $0.955^{*}$ & 0.874 & 0.932 & 0.727 & 0.840 & $0.984 *$ & 0.765 & 0.923 & 1 \\
\hline
\end{tabular}

Temp. temperature, $D O$ dissolved oxygen, $B O D$ biological oxygen demand, $T D S$ total dissolved solids, $E C$ electrical conductivity, $T H$ total hardness, $T A$ total alkalinity, $T H B$ total heterotrophic bacteria, $T C$ total coliform, $F C$ fecal coliform, $V C V$. cholerae

*Correlation is significant at the 0.05 level (2-tailed). ${ }^{* *}$ Correlation is significant at the 0.01 level (2-tailed)

\section{References}

Al-Kareem AAF, Al-Arajy KH, Jassim KA (2015) Microbiological analysis on Tigris River water in the selected sites in Baghdad province. Iraq J Environ Earth Sci 5(6):60-64

APHA (1981) Standard methods for the examination of water and wastewater, 15th edn. APHA, Washington

APHA (1995) Standard methods for the examination of water and wastewater, 19th edn. APHA, Washington, p 1467

APHA (1998) Standard methods for the examination of water and wastewater, 20th edn. APHA, Washington

Baghel VS, Gopal K, Dwivedi S, Tripathi RD (2005) Bacterial indicators of faecal contamination of the Gangetic river system right at its source. Ecol Indic 5:49-56

Banglapedia (2004) National Encyclopedia of Bangladesh. Asiatic Society of Bangladesh. 5 Old Secretariat Road Nimtali Dhaka-1000

Behbahaninia A, Mirbagheri SA, Khorasani Nouri J, Javid AN (2009) Heavy metal contamination of municipal effluent in soil and plants. J Food Agric Environ 7(3-4):851-856

Bhouyan AM (1979) Effect of industrial pollution on the biology of the Karnafully River. M. Phil. Thesis, University of Chittagong, Bangladesh, p 164

Boyle TP, Fraleigh HD (2003) Natural and anthropogenic factors affecting the structure of the benthic macro invertebrate community in an effluent- dominated reach of the Santa Cruz River, AZ. Ecol Indic 3(2):93-117

Chandra R, Singh S, Raj A (2006) Seasonal bacteriological analysis of Gola River water contaminated with pulp paper mill waste in Uttaranchal, India. Environ Monit Assess 118:393-406

Crowther J, Kay D, Wyer MD (2001) Relationships between microbial water quality and environmental conditions in coastal recreational waters. The fylde coast, U.K. Water Res 35:4029-4038

Dahunsi SO, Owamah HI, Ayandiran TA, Oranusi US (2014) Drinking water quality and public health of selected communities in South Western Nigeria. Water Qual Exp Health 6:143-153
Department of Environment (DoE) (1997) Environmental quality standard for Bangladesh. Ministry of Environment and Forestry, Dhaka

El-Fadaly H, El-Defrawy M, El-Zawawy F, Makia D (2001) Chemical and microbiological evaluation of river Nile water in Dakahlia Governorate. J Environ Sci 22:1-18

Ezzat SM, Hesham M, Mahdy MA, Abo-State E, Abd El-Shakour H, El-Bahnasawy MA (2012) Water quality assessment of river Nile at Rosetta branch: impact of drains discharge. Middle-East J Sci Res 12:413-423

Farnleitner AH, Hocke L, Beiwl C, Kavka GG, Zechmeister T, Kirschner AKT, Mach RL (2001) Rapid enzymatic detection of Escherichia coli contamination in polluted river water. Lett Appl Microbiol 33:246-250

Garnier J, Servais P, Billen G (1991) Bacterioplankton in the Seine River: impact of the Parisian urban effluents. Can J Microbiol 38:56-64

Isobe KO, Tarao M, Chiem NH, Minh LY, Takada H (2004) Effect of environmental factors on the relationship between concentrations of coprostanol and fecal indicator bacteria in tropical (Mekong delta) and temperate (Tokyo) freshwaters. Appl Environ Microbiol 70:814-821

Jithesh M, Radhakrishnan MV (2015) Seasonal variation in microbial population of Chaliyar River water Kerala, India. Int J water Res 5(2):64-69

Kavka GG, Poetsch E (2002) Microbiology. In: Literathy P, Koller Kreimel V, Liska I (eds) Technical report of the international commission for the protection of the Danube River. Eigenverlag ICPDR, Vienna, pp 138-150

Kenyon JE, Piexoto DR, Austin B, Gillies DC (1984) Seasonal variation in numbers of Vibrio cholerae non-O1 from coastal California waters. Appl Environ Microbiol 47:1243-1245

Koelle K, Rodo X, Pascual M, Yunus M, Mostafa G (2005) Refractory periods and climate forcing in cholera dynamics. Nature 436(7051):696-700 
Koshy M, Nayar TV (1999) Water quality aspects of river Pamba. Pollut Res 18:501-510

Mahmood N, Chowdhury MSU, Hossain MM, Haider SMB, Chowdhury SR (1992) Review of the state of environment relating to marine fisheries of Bangladesh. Country status report. BOBP (FAO) MS. CU, p 85

Mishra S, Singh AL, Tiwary D (2014) Studies of physico-chemical status of the ponds at Varanasi Holy City under Anthropogenic influences. Int J Environ Res Dev 4(3):261-268

Mtui GVS, Nakamurs Y (2006) Physiochemical and microbiological water quality of lake Sagara in Malagarasi wetlands. J Eng Appl Sci 1(2):174-180

Neumann DA, Benemon H, Hubster E, Thinhutuan N, Tie-van L (1972) Vibrio parahaemolyticus in the Republic of Vietnam. Am J Trop Med Hyg 22:464-470

Prasanna MB, Ranjan PC (2010) Physico chemical properties of water collected from Dhamra estuary. Int J Environ Sci 1(3):329-334

Prescott L, Harley J, Klein D (1996) Microbiology, 3rd edn. WCB Publishers, Chicago

Rai KA, Paul B, Kishor N (2012) A study on the sewage disposal on water quality of Harmu River in Ranchi city Jharkhand, India. Int J Plant Anim Environ Sci 2(1):102-106

Roy Y, Kumar RA (2002) A study of water quality of the rivers of Ranchi district. Ind J Environ Prot 21(5):398-402

Sabae ZS, El-Sheekh MM, Khalil AM, El-Fattah AW, Badr MH (2014) Seasonal and regional variation of physicochemical and bacteriological parameters of surface water in El-Bahr El Pherony, Menoufia, Egypt. World J Fish Marine Sci 6(4):328-335

Singh SP, Pathak D, Singh R (2002) Hydrobiology of two water bodies i.e. Jagatdev and Narayan ponds of Satna (M.P). Ecol Environ Conserv 8:289-292

Tiefenthaler LL, Stein ED, Lyon GS (2008) Fecal Indicator Bacteria (FIB) Level during dry weather from southern California reference streams. Southern California Costal Water Research Project, Technical report 542

Vincent N, Veronica JA, Charles AU, Stella IO, Ameh J (2006) Study of the bacteriological and physicochemical indicators of pollution of surface waters in Zaria, Nigeria. Afr J Biotech 5(9):732-737

World Health Organization (2003) Nitrate and nitrite in drinking water. Background document for preparation of WHO guidelines for drinking water quality. World Health Organization, Geneva

World Health Organization (2008) Guidelines for drinking-water quality, vol 1, 3rd edn. WHO, Geneva, p 494

Publisher's Note Springer Nature remains neutral with regard to jurisdictional claims in published maps and institutional affiliations. 